University of Washington Tacoma

UW Tacoma Digital Commons

SIAS Faculty Publications

School of Interdisciplinary Arts and Sciences

$11-1-2013$

\title{
Secondary flow deflection in the lee of transverse dunes with implications for dune morphodynamics and migration
}

Ian J. Walker

Dan H. Shugar

University of Washington Tacoma, dshugar@uw.edu

Follow this and additional works at: https://digitalcommons.tacoma.uw.edu/ias_pub

\section{Recommended Citation}

Walker, Ian J. and Shugar, Dan H., "Secondary flow deflection in the lee of transverse dunes with implications for dune morphodynamics and migration" (2013). SIAS Faculty Publications. 338.

https://digitalcommons.tacoma.uw.edu/ias_pub/338

This Article is brought to you for free and open access by the School of Interdisciplinary Arts and Sciences at UW Tacoma Digital Commons. It has been accepted for inclusion in SIAS Faculty Publications by an authorized administrator of UW Tacoma Digital Commons. 
1 Can transverse dunes move sideways? Secondary flow deflection in the lee of transverse

2 dunes with implications for dune alignment and migration

3

4

5

6

7

8

9

10

11

12

lan J. Walker*

Department of Geography

University of Victoria

P.O. Box 3050, Station CSC

Victoria, British Columbia

Canada V8W3P5

Tel: (250) 721-7347 Fax: (250) 721-6216

ijwalker@uvic.ca

\section{Dan H. Shugar}

Department of Geography

University of Victoria

P.O. Box 3050, Station CSC

Victoria, British Columbia

Canada V8W3P5

Tel: (250) 472-5930 Fax: (250) 721-6216

dshugar@uvic.ca

*corresponding author 
34 Measurements of lee-side airflow response from an extensive array of meteorological instruments

35 combined with smoke and flow streamer visualization is used to examine the development and

36 morphodynamic significance of the lee-side separation vortex over closely spaced transverse dune

37 ridges. A differential deflection mechanism is presented that explains the three-dimensional pattern

38 of lee-side airflow structure for a variety of incident flow angles. These flow patterns produce

39 reversed, along-dune and deflected surface sand transport in the lee that result in a net 'lateral

40 diversion' of sand mass transport over one dune wavelength for incident angles as small as $10^{\circ}$

41 from crest-transverse (i.e., $80^{\circ}$ from the crest line). This lateral displacement in fluid mass transport

42 increases markedly with incident flow angle, when expressed as the absolute value of the total

43 deflection in degrees. Reversed flow and multidirectional sand transport occur for incident angles

44 between 90 and $50^{\circ}$. These results document the three-dimensional nature of flow and sand

45 transport over transverse dunes and provide empirical evidence for an oblique migration model that

46 challenges the applicability of the 'gross bedform-normal' rule for explaining transverse dune

47 morphodynamics and migration.

48

49 KEYWORDS: dunes, airflow, deflection, lee-side, interdune, dune migration 
The relations between the near-surface airflow field (i.e., height $<10 \mathrm{~m}$ ), particularly complex secondary lee-side flows, and sediment transport over dunes remain an elusive challenge

53 for modeling dune morphodynamics and migration (Walker and Nickling, 2002; Baddock et al.,

54 2007; Livingstone et al., 2007). It is known that dune form, alignment, and spacing are controlled by

55 the magnitude, frequency, and directionality of transporting surface wind (e.g. Bagnold, 1941;

56 Fryberger and Dean, 1979; Lancaster, 1983; Bullard et al., 1996; Ould Ahmedou et al., 2007) as

57 well as sediment characteristics (size and sorting) (Wilson, 1972) and availability (Wasson and

58 Hyde, 1983), moisture effects (Kocurek et al., 1992), topographic barriers (McCauley and Breed,

59 1980), and the presence of vegetation (Hesp, 1981; 1983; Wiggs et al., 1996). Other studies have

60 linked dune alignment to coherent atmospheric circulation patterns such as Ekman spirals (Hanna,

61 1969; Mabbut et al., 1969; Warren, 1976) and to the strongest transporting winds in the regime

62 (Glennie, 1970). Ultimately, however, dune alignment and migration is the net result of complex,

63 three dimensional sand transport patterns driven by all competent surface winds - including

64 secondary lee-side flows (Sweet and Kocurek, 1990; Frank and Kocurek, 1996; Walker and

65 Nickling, 2002; Baddock et al., 2007; Livingstone et al., 2007; Baddock et al., 2011; Weaver and

66 Wiggs, 2011). Nearly 30 years ago, Rubin and Hunter (1985), and later Hesp et al. (1989) and

67 Rubin (1990), observed that longitudinal dunes can migrate laterally, contrary to the prevailing

68 thought that such dunes advance downwind, or else extend at the terminal end (e.g. Bagnold,

69 1941; Tsoar, 1983). To date, however, there is limited research that links deflected airflow and

70 sediment flux in the lee of transverse dunes to their morphodynamics and migration (Walker, 1999;

71 Walker and Nickling, 2002; Baddock et al., 2007).

74 (transport-parallel), and oblique $\left(15-75^{\circ}\right.$ to the resultant transport direction) forms (Fryberger 
75 and Dean, 1979; Hunter et al., 1983; Lancaster, 1983; Rubin and Ikeda, 1990). Fryberger and

76 Dean's (1979) widely cited global assessment attributed the development and maintenance of

77 specific dune types to the ratio of the resultant vector of sand transport, or drift potential (RDP), to

78 total drift potential from all wind directions (DP). Fryberger and Dean found that simpler dune forms

79 (e.g., barchans, transverse ridges) develop in less variable wind regimes with high sand transport

80 potential (RDP/DP) while more complex dunes (e.g., star dunes) occur in highly variable wind

81 regimes where the transport potential is lower.

82 Regional winds used to describe dune form using Fryberger and Dean's (1979) technique

83 are usually measured at a standard height of $10 \mathrm{~m}$, often from locations tens to hundreds of

84 kilometers away from actual dune features (Hunter et al., 1983; Carson and MacLean, 1986).

85 However, localized secondary airflow patterns such as flow deflection, topographic steering, and

86 flow separation and reversal, often diverge greatly from the regional trend (e.g. Pearce and Walker,

87 2005; Lynch et al., 2008; 2009; Walker et al., 2009; Jackson et al., 2011) and can be competent

88 enough to drive deflected interdune sand transport (Walker, 1999) and, thus, contribute to three-

89 dimensional variations in dune sediment budgets. Thus, simple regional assessments of wind

90 regime - dune form relations may be insufficient as they do not accommodate more complex

91 natural flow - form - transport interactions (Walker and Nickling, 2002).

92 This has generated some debate in the literature on wind regime - dune form relations

93 (Hunter et al., 1983; Carson and MacLean, 1985; Hunter et al., 1985; Carson and MacLean, 1986).

94 For instance, Carson and McLean (1986) noted an increase in oblique dune size in a reversing

95 wind regime toward the direction of an along-dune oriented resultant transport vector (shown in

96 their Figure 5). This complicated their interpretation of these dunes as true flow-transverse forms

97 and they suggested the term 'hybrid' dunes as both longitudinal and transverse transport

98 processes appeared to be contributing to their morphodynamics. This is essentially synonymous

99 with the 'oblique' dunes documented earlier by Hunter et al. (1983) in coastal Oregon. In either 
case, it is possible that the resultant sand transport vector (RDP), driven by winds transverse or

101 slightly oblique to the dune crest, may actually align more so with deflected, along-dune oriented

102 lee-side secondary flow patterns. Sand transport by such secondary winds may be responsible for

103 the downwind 'bulking' of Carson and MacLean's dunes (1986, see p.1983-1984).

Other studies have shown that directional variability (i.e., dominant modes in the regional

wind regime) control dune morphodynamics and alignment. For instance, Rubin and Hunter (1987) and Rubin and Ikeda (1990) showed that dune alignment follows a gross bedformnormal rule such that, under variable flow directions, bedforms align so as to maximize the amount of crestline-normal transport. In other words, bedforms orient as transverse as possible to the resultant of all bedform-normal transport components and not necessarily to the resultant transport vector. Rubin and Ikeda (1990) stressed that opposing vector components in the transport regime should not be cancelled out (as in the RDP approach) as they may both be formative in maintaining a single dune orientation. For instance, transverse forms are maintained for divergence angles (i.e., angle between dominant direction modes) up to $90^{\circ}$ or equal to $180^{\circ}$ (i.e., a reversing regime), or when transport is dominated by one direction mode. Longitudinal dunes often orient with the dune axis within $15^{\circ}$ of the mean wind direction (Hunter et al., 1983) and are maintained in bi-modal wind regimes with divergence angles $>90^{\circ}$ providing equivalent transport in both directions. As such, dune-parallel wind flow is not a requirement for longitudinal bedform maintenance (Lancaster, 1982; Tsoar, 1983; Rubin and Ikeda, 1990). Transitional, or oblique dunes occur for intermediate divergence angles from 90 to $112.5^{\circ}$ (or 'obtuse-bimodal' per Fryberger and Dean, 1979) and are controlled by both transverse and along-dune oriented transport processes (Carson and MacLean, 1986). Rubin and Ikeda (1990) conclude that, despite alignment, all free dune forms are governed by the same essential dynamics in that they will orient as perpendicular as possible to the maximum bedform-normal components of transport. As such, divergence between directional modes and the ratio of sand 
transport by these modes is more important in dune maintenance and migration than the net resultant vector. the regional scale sand transport regime assessments provide only a first order estimate of the transport regime and are unable to incorporate other key transport- and supply-limiting factors (including grain size, soil moisture, vegetation, surface roughness) as has been explored by subsequent research on aeolian sand transport potential and dune mobility (e.g. Muhs and Maat, 1993; Gaylord and Stetler, 1994; Muhs and Holliday, 1995; Wiggs et al., 1995; Bullard et al., 1996; Wolfe, 1997; Tsoar and Illenberger, 1998; Kocurek and Lancaster, 1999; Muhs and Wolfe, 1999; Lancaster and Helm, 2000; Tsoar, 2002). These factors are particularly important when examining regional to landform-scale characterizations of sand transport behaviour in vegetated, temperate and/or coastal environments (Pearce and Walker, 2005; Lynch et al., 2008; 2009; Walker et al., 2009; Jackson et al., 2011). examining landform scale interactions between near-surface secondary flow and resulting sand transport patterns that drive dune morphodynamics in both coastal and desert settings (e.g. Tsoar, 1983; Howard, 1985; Hesp et al., 1989; Rasmussen, 1989; Cooke et al., 1993; Arens et al., 1995; Lancaster, 1995; Hesp and Hyde, 1996; Wiggs, 2001; Walker and Nickling, 2002; Baddock et al., 2007; Ould Ahmedou et al., 2007; Lynch et al., 2008; 2009; Walker et al., 2009; Weaver and Wiggs, 2011). Despite this recognition, very few models of secondary flow and dune morphodynamics exist, particularly on how these flow and sand transport patterns change with the incident flow angle and what this means for dune sediment budgets and migration (Walker and

147 Nickling, 2002; Hesp and Walker, In press). Instead, most existing models of flow over bedforms view the system as two-dimensional and consider only limited flow conditions (i.e., transverse, unseparated) over relatively isolated dunes (Sweet and Kocurek, 1990; Frank and Kocurek, 1996; 
Baddock et al., 2011). However, in nature secondary flows and closely spaced dune configurations generate mass and energy transfers that are three-dimensional. For instance, Walker (1999) showed that appreciable sand transport can occur in deflected, reversed, and along-dune directions within the interdune and cautioned that secondary lee flows create additional mass transport components that must be considered for sediment continuity and, hence, for interpretation of dune dynamics, maintenance, and migration.

This study measures and examines the responses of three-dimensional lee-side flow structure and interdune sand transport to changes in incident flow angle. Flow visualization and concurrent measurements of lee-side sediment transport over the same dune (Walker, 1999) are used to show a lateral diversion of sand mass transfer over flow-transverse dunes. From this, a differential deflection mechanism is presented that explains secondary lee-side flow structure implications for dune maintenance and migration. An empirical model for oblique migration of transverse dunes is presented that challenges the applicability of the 'gross bedform-normal' rule for explaining dune morphodynamics. The convention to describe flow direction for this study is such that incident wind direction, $\mathrm{i}$, measured at the crest of the dune is transverse to the crestline at $90^{\circ}$ and parallel to the crestline at $0^{\circ}$ (west) or $180^{\circ}$ (east). When discussing deflected flow, $\mathrm{d}$, in the lee of the study dune on the stoss slope of the downwind dune, we use the same coordinate system as for incident flow. For example, incident flow transverse to the crest $\left(i=90^{\circ}\right)$ might be deflected $10^{\circ}\left(\mathrm{d}=100^{\circ}\right)$ in the lee.

\section{METHODS}

Wind speed and direction were measured along two crest-transverse transects spaced approximately $18 \mathrm{~m}$ apart in the lee of a small reversing dune in the Silver Peak dunefield, Clayton Valley, west-central Nevada (Walker, 1999) (Figure 1). Dune geometry differed slightly between

Comment [D1]: lan, how's this expanded description of $i$ and $d$ ?

Comment [IW2]: Presumably, you wanted to add the symbol i here? I also thinned e/w text a bit.

Comment [IW3]: This font looks weird in my vers. 
$m$ ). The study dune was located within a successive grouping of similarly sized ( $h=1$ to $2 \mathrm{~m}$ ), unvegetated, transverse ridges composed of fine sands $(D=150 \mu \mathrm{m})$ and oriented transverse $\left(75^{\circ}\right.$ or approximately E-W) to a relatively consistent north-south reversing wind regime. During the period of study the dune profile had a sharp crestline with a distinct, southward facing lee slope.

Each instrument transect extended $12 \mathrm{~m}$ leeward and perpendicular to the crest and consisted of 25 RM Young cup anemometers and six wind vanes strategically located to capture windspeed and direction variations in the immediate lee (Figures 2, 3). Instruments were extended on 1.2-m booms from one of four aluminum masts and were connected to dataloggers via cable. Near-surface anemometers were placed at $0.3 \mathrm{~m}$ to characterize transporting windspeeds $\left(\mathrm{u}_{0.3}\right)$. Further details of the study site and sampling design are discussed in Walker (1999; 2000).

Extended periods of consistent winds ranging in duration from 1 to 10 hours were sampled at $1 \mathrm{~Hz}$ and recorded as one-minute averages by datalogger. All speeds were normalized by an outer windspeed $\left(\mathrm{u}_{10 \mathrm{~h}}\right)$ measured at $12.4 \mathrm{~m}$ (approximately $10 \mathrm{~h}$ ) above the interdune datum atop an observation tower located between the sampling transects, where wind speeds ranged from 2 to $15 \mathrm{~m} \mathrm{~s}^{-1}$ during the period of study. Incident flow speed and direction data were also measured at $3.8 \mathrm{~m}$ above the dune on the crest profile (i.e., $u_{5.2 \mathrm{~h}}$ on east and $\mathrm{u}_{4.6 \mathrm{~h}}$ on west profiles, respectively). In total, 45 events were recorded over a 15-day period in May 1997 to yield an extensive dataset of over 22,000 minutes of flow measurements for a variety of incident flow speeds and directions. Contiguous transporting flow events (i.e., above an assumed transport threshold of $6 \mathrm{~m} \mathrm{~s}^{-1}$ ) ranging 7 to 24 minutes in duration and spanning incident flow angles were identified (Table 1). These events all occurred on the same day and, as such, dune form remained essentially constant between events.

Flow patterns during the events presented here were also visualized using smoke tracers and a vertical array of streamer flags (Figure 4), which was essential for reconstructing lee side flow structure within the measurement array. A transect of 9 flow streamer towers was erected $2 \mathrm{~m}$
Comment [D4]: I think I've now fixed everything to U5.2h and U4.6h

Comment [IW5]: OK... now, do we refer to these 5.2 and 4.6h measurements or is everything always normalized by uouter/10h? For e.g., I think the vectors are normalized by their respective crest outer measurements, not $10 \mathrm{~h}$., whwereas the profiles may have been. Doublecheck and clarify. 
east of a 12-m observation tower in the centre of the study site (Figure $2 b$ ). The streamer towers

201 were spaced $1 \mathrm{~m}$ apart and extended leeward from the crestline. Each tower was $3 \mathrm{~m}$ tall and had

2025 streamer flags each. Flow streamer behaviour in plan view at different heights above the

203 interdune surface was recorded by video camera from atop the observation tower in the centre of

204 the instrument array. Smoke tracer patterns were photographed in profile from the interdune

205 corridor. Both sources of flow visualization were used to qualitatively confirm measured flow

206 responses and help construct the extent and behaviour of interpreted flow patterns from the

207 instrument array.

208

209 RESULTS

210 Time-averaged velocity profiles

211 Time-averaged, normalized wind speed profiles for six locations on each dune transect are

212 shown in Figure 5. For clarity, data from only three events (2, 4, and 7$)$ ranging from transverse (i

$213 \approx 90^{\circ}$ ) to crest-parallel $\left(\mathrm{i} \approx 180^{\circ}\right.$ ) are shown. Summary statistics are provided in Table 1 . Profile

214 gradient responses provide a good relative indicator of momentum extraction and fluid shear

215 generated by the form as well as subsequent internal boundary layer redevelopment after

216 reattachment.

For relatively transverse (event $2, \mathrm{i} \approx 90^{\circ}$ ) and slightly oblique (event $4, \mathrm{i} \approx 110^{\circ}$ ) winds, flow

218 over the crest was nearly uniform with increasing height above the surface for both east and west

219 transects, whereas for crest-parallel flow (event $7, i \approx 180^{\circ}$ ), a slightly kinked velocity profile was

220 observed over the crest on both transects. On the east profile, the inflection point occurred only 0.7

$221 \mathrm{~m}$ above the crest surface (1.5h above interdune datum) for event 7 , while on the west profile, it occurred at $1.6 \mathrm{~m}$ above the surface $(2.4 \mathrm{~h})$. On the east profile, the crest-parallel incident flow 
(event 7) was fastest at the highest sensor, $3.8 \mathrm{~m}$ above the crest surface $(5.2 \mathrm{~h})$, while on the west profile, crest-parallel incident flow was slightly less than the transverse incident flow (4.6h, event 2).

All three events shown in Figure 5 exhibited similar general trends in lee-side flow profile response, although magnitudes differed. Flow visualization confirmed that flow separation and intermittent reversal was present for all transverse wind events. In general, crest-parallel incident flows were faster over lee slope (near-surface) and stoss locations than other flows. Lee slope profiles for crest-transverse and oblique flows were inflected with a very steep gradient below dune height. This is due to flow separation and wake sheltering effects and indicates a region of high shear along the line of separation. The speed-height gradient was steeper for transverse incident flow (event 2) than for crest-parallel incident flow (event 7). On the east profile, near-surface flow was slowest in event 2, and fastest for event 7 . Higher into the flow over the lee slope of the east profile, flow during event 7 (crest-parallel incident flow) was only marginally slower than other incident conditions. Over the lee slope of the west profile, near-surface speeds were generally faster than over the east transect, but during event 4 (initially slightly oblique to the crest), flow was slightly faster than during crest-parallel incident flow (event 7). As on the east profile, flow during event 7 had the shallowest gradient. flow returned to a linear velocity profile. Flow visualization and onsite ripple patterns revealed that flow reattachment occurred between the interdune and stoss base locations on the east transect and further downwind between the stoss base and lower stoss I profiles on the west transect. locations in the flow field where a wind vane and anemometer were co-located (see Figures 2, 3b). 
secondary flow region compared to outer flow above the dune crest.

Figure 6 shows lee-side flow vector response for three crest-transverse events that increase in speed (events 1-3). Incident flow speeds at the top of the crest profiles $\left(u_{5.2 h}\right.$ on east, $u_{4.6 h}$ on west) ranged from $0.84-0.92$ of the outer flow $(10 \mathrm{~h})$ and variability was less than $10 \%$ (i.e., $\mathrm{CV}_{\mathrm{ui}}<$ 0.10). Incident direction ranged $\pm 2^{\circ}$ from transverse (e.g. $i=88$ to $92^{\circ}$ ) and directional variability was less than $6^{\circ}$ for all events. Overall variability in direction increased with incident speed although steadiness in flow speed was highest at faster speeds (see $\mathrm{CV}_{\mathrm{u}}$ values in Figure $6 \mathrm{c}$ ). with bi- or multi-modal directional variation indicating flow deflection and unsteadiness. Intermittent upslope (reversed) flow was observed at these locations but is not reflected in the vectors because of the relatively long (1 min.) averaging intervals. Speeds on the lee slope ranged approximately 30 to $70 \%$ that of the outer flow at $10 \mathrm{~h}$ and were slower on the east transect due to the increased sheltering offered by the taller dune. This sheltering effect increased with incident speed at all lee slope locations. The amount of flow deflection on the lee slope also increased with speed and dune height.

There are two flow vector measurement points on the interdune and stoss base profiles 265 that are staggered slightly for strategic placement within the separation region (see Figures 2, 3b).

266 The interdune vectors, located just downwind of the lee slope base, characterized flow in the core 267 of the separation cell $\left(2^{\text {nd }}\right.$ sensor, $0.8 \mathrm{~m}$ above surface $)$ and just above crest height $\left(4^{\text {th }}\right.$ sensor, 1.8 $268 \mathrm{~m})$. Vectors on the stoss base profile were located on the toe of the downwind dune the surface $269(0.3 \mathrm{~m})$ and just above dune height $(1.3 \mathrm{~m})$. Over the interdune, flow at half-dune height was 270 deflected more than that on the lee slope surface. Variability in direction at this location increased 271 with incident speed and reversed flow occurred within the separation cell at the highest incident 272 speed on the west transect (Figure 6c). Highly variable, multi-modal reversed flow was also 
274 at this location (particularly on the west transect) indicate high turbulence along the shear zone, as

275 described above from Figure 5. Speeds above the separation cell in the interdune were

276 comparable to incident speeds $3.8 \mathrm{~m}$ above the crest $\left(u_{5.2 h}\right.$ and $u_{4.6 h}$ for east and west profiles,

277 respectively) and, in general, were faster than at the stoss base location downwind due to flow

278 expansion (and deceleration) downwind of separation at the crest.

Surface vectors at the toe of the downwind dune (stoss base) were multi-modal on the east transect and strongly oblique to incident flow. Flow visualization and surface ripple patterns showed that this location was just downwind of flow re-attachment. Upper and half-height flow vectors were also multi-modal but more aligned sub-parallel to incident flow. Half-height vectors on the west transect were deflected more than those on the east transect. These vectors show that nearsurface deflection is greater (at the toe of the downwind dune, or near the point of re-attachment) over the taller dune (east) and that this pattern increased with faster incident speeds. This suggests that the flow separation cell was slightly larger over the taller dune and for faster wind speeds, as expected. Flow direction above this location (upper height) was less variable and less deflected than at half-height. The lower stoss vector (furthest downwind), which was higher above the surface, showed low variability in direction, was aligned more crest-transverse, and had slower relative speeds than the stoss base location. This indicates flow direction returning to cresttransverse up the stoss of the downwind dune.

Figure 7 shows lee-side flow vector response for two oblique flow events with incident angles of approximately $110^{\circ}$ (event 4 , Figure 7a) and $130^{\circ}$ (event 5, Figure 7b). These events show that the amount of flow deflection on the lee slope increased with the angle of obliquity (approximately doubling with a twofold increase in obliquity angle from transverse) and for the taller dune (e.g., from $24^{\circ}$ to $40^{\circ}$ on the taller east transect compared to only $3^{\circ}$ to $7^{\circ}$ on the shorter west 
the lee slope through stoss slope regions show that flow deflection was greatest near the surface

(reaching a maximum at the stoss base surface location) and decreased with height and beyond inclusive (Figures 7, 8).

Flow vector response for highly oblique to crest-parallel events $6\left(i \approx 145^{\circ}\right)$ and $7\left(i \approx 0^{\circ}\right)$ are shown in Figure 8. Event 6 exhibited a similar deflection trend as events 4 and 5. Although the absolute magnitudes of deflection angles were greater, they generally decreased with height and distance beyond the interdune. Lee slope flow deflected by about $30^{\circ}$ on the taller (east) dune $(\mathrm{i}=$ $146^{\circ}, d=177^{\circ}$ ) but was deflected negligibly over the shorter (west) dune ( $i=146^{\circ}, d=147^{\circ}$ ). Normalized windspeeds elsewhere in the lee (from anemometer-only locations that could not be converted to vectors, see Figure 5 a for velocity profiles) were faster than crest values at all locations beyond the lee slope on the east transect and in the immediate lee and interdune regions on the west transect. Near-surface lee slope speeds during this event were 0.59 and 0.84 that of the outer flow on east and west transects respectively. Speeds and flow deflection were greatest within the interdune to stoss base regions on both transects, which indicates strong along-dune flow within the interdune corridor.

Flow direction for event 7 (Figure $8 b$ ) was aligned approximately parallel to the crest and unlike all other events was from the west $\left(i=2^{\circ}-3^{\circ}\right)$. All lee-side locations recorded faster flow than 


\section{DISCUSSION}

\section{Lee-side flow deflection and secondary flow structures}

Flow-form interactions over complex dune terrain generate significant alterations in the

magnitude and direction of near-surface sand-transporting winds. This results from topographically forced variations in the pressure field over dunes and creates various secondary flow patterns including flow accelerations on the stoss slope; flow separation, expansion, and reversal in the lee; and directional variations of attached, near-surface flow that is deflected or steered in directions that differ significantly from the regional wind (Walker and Nickling, 2002; Walker et al., 2006; Walker et al., 2009). Research on flow over coastal foredunes has shown that, generally, winds approaching at an oblique angle tend to be deflected toward crest-normal with approach angles less than $30^{\circ}$ (i.e., highly oblique) are often deflected parallel to the crest (e.g. Mikkelsen, 1989; Arens et al., 1995). Crestward steering on the stoss slope occurs essentially because perturbation pressures and resulting topographic flow accelerations increase the crest-normal (transverse) component of local flow vectors up the stoss slope local flow vectors that, in turn, causes flow to deflect in a more crest-parallel direction (Tsoar, 1983; Walker, 1999). The morphodynamic implications of flow deflection are twofold. First,

Comment [IW12]: I think there is a walker et al ref 2006 maybe that also shows this and should be added.

Comment [IW13]: Again, I think one of our PE papers also showed this... don't have access to them at the mo, however. Add if you can. 
(1995). More transverse incident winds appear to be deflected more than airflow aligned oblique or

parallel to the crest. This results from steeper pressure gradients over the dune under more

transverse flow conditions. In other words, the apparent 'steepness' (or aspect ratio) of the dune as

experienced by incoming airflow varies significantly depending on the incidence angle and dune

height; airflow perpendicular to the crest will encounter a much steeper dune and will generate a

larger separation cell than will airflow that approaches at more oblique incident angles (Baddock et

al., 2011; Walker and Hesp, In press). This can result in less flow deceleration in the lower stoss

and reduced transport potential up the stoss slope (see discussion in Walker et al., 2006). In

this study, lee-side flows were fastest when incident flow over the crest was crest-parallel,

reflecting a lower aspect ratio and reduced, or non-existent separation (and recirculation) cell.

Over transverse dunes, Sweet and Kocurek (1990) documented that lee slope windspeeds

approached zero as incident angle became more transverse (i.e., as i approaches $90^{\circ}$ ) due to

flow separation. Lee slope speeds increased rapidly between $\mathrm{i}=70$ to $90^{\circ}$. Sweet and Kocurek

(1990) concluded that dune shape was an important control on lee flow response such that dunes with low aspect ratios and/or oblique incident winds favoured attached and relatively high lee-side surface windspeeds while dunes with high aspect ratios and/or transverse incident flows demonstrated lower speeds (e.g. Best and Kostaschuk, 2002). In terms of sediment transport, 

and were associated with along-slope sediment transport. Transverse flows favoured sediment avalanching and fallout incident wind conditions documented in this study show that lee-side flow deflection often aligned sub-parallel to the crest. At three sites in the Netherlands, Arens et al. (1995) found similar deflection to crest-parallel in the lee of coastal foredunes during offshore winds, but towards crestnormal during onshore winds. Over a 12-m high, steep foredune in Prince Edward Island, Canada, Walker et al. (2009) observed significant onshore steering of near-surface flow towards crestnormal. In an earlier study on a nearby 9-m high foredune, Walker et al. (2006) observed offshore to oblique onshore winds being steered alongshore on the beach and even deflected back toward the foredune, resulting in sand being cycled along the beach and back to the dune, thus promoting dune maintenance. A series of studies at Magilligan Strand, Northern Ireland, have shown that lee-side flow response is also governed by variations in morphology as well as incident flow angle (Lynch et al., 2008; 2010; Jackson et al., 2011), where attached and deflected lee-side flow is thought to arise when the abrupt break in slope required for separation is absent. Lynch et al. (2010) observed varying flow response over dunes of different heights and shapes. A tall (11.4-m) sharp-crested foredune produced flow separation and a recirculation cell. A smaller (6.6-m tall), rounded foredune exhibited attached lee-side flow that was deflected towards crest-parallel, while flow over a lower (4.6-m tall), incipient foredune exhibited no flow deflection in the lee. In an earlier study, Lynch et al. (2008) demonstrated that offshore winds that result in flow reversal do not significantly contribute to sand drift potential. Instead, it was winds deflected alongshore that were associated with the most saltation activity. They conclude therefore, that these deflected flows should be considered a key variable when linking microand meso-scale sediment transport studies.

Comment [IW18]: These are the refs I was referring to cite earlier, as you see fit.
Comment [IW19]: This is pretty good. Thanks for working it in. Just watch, though, someone will criticize us for incorporating the coastal lit as these dunes have veg (additional roughness) and are typically more steep than any desert dunes (which results in steeper pressure gradients). Perhaps a sentence or 2 to highlight the differences at the end would be a good idea, thereby stressing the point that more work on deflection and morphology need be done in desert settings, perhaps? 
399 in the range of 20 to $40^{\circ}$ was observed (Figure 8). Others have found that the magnitude of 400 deflected flow on the lee slope is a cosine function of the angle of incidence and crest speed 401 (Tsoar, 1983; Tsoar et al., 1985; Sweet and Kocurek, 1990; Lancaster, 1995). A wind tunnel study 402 by Tsoar et al. (1985)-explored the -influence- of 3 incident flow angles $\left(15^{\circ}, 25^{\circ}\right.$, and $35^{\circ}$-relative-to 403 the crest) on lee-side flow separation and deflection over linear dunes. They found that lee-side 404 flow deflects from the incident direction toward that aligned with the crest and that sediment 405 transport patterns follow this deflection pattern. Earlier field research by Tsoar (1983) showed that 406 the rate of sand transport increased for more oblique angles when $\mathrm{i}<40^{\circ}$ and that deposition on 407 the lee flank of a longitudinal (seif) dune occurred as incident flow angles became more transverse. Over transverse dunes, Sweet and Kocurek (1990) documented that lee slope windspeeds approached zero as incident angle became more transverse due to flow separation. Lee slope speeds increased rapidly as i approached $70^{\circ}$ and Sweet and Kocurek (1990) concluded that dune shape was an important control on lee flow response such that dunes with low aspect ratios and/or oblique incident winds favoured attached and relatively high lee-side surface windspeeds, while dunes with high aspect ratios and/or transverse incident flows demonstrated lower speeds. These observations are similar to those made in fluvial environments (e.g. Best and Kostaschuk, 2002; Kostaschuk et al., 2009);-- where flow over low angle dunes tends to remain attached and flow reversal is relatively rare. Compiling data from several rivers, Kostaschuk (2005) concluded that deposition of suspended sediment in the trough and on the dune lee side acts to reduce dune height and lower the lee slope angle, thus underscoring earlier studies (e.g. Smith and McLean, 1977; Kostaschuk and Villard, 1996; Kostaschuk, 2000) that showed that increased suspended sand transport relative to bedload, was associated with flatter dunes and lower lee slope angles. In terms of aeolian sediment transport, Sweet and Kocurek (1990) observed that deflected lee flow speeds were 60 to $80 \%$ of crest speeds and were associated with appreciable along-slope
Comment [IW20]: Don't think we need to ital. for the draft and some journals don't anyway.

Comment [IW21]: fix/replace: e.g., and i.e., always have commas.

Comment [IW22]: Hmm... maybe l'm missing something but not sure how this relates to aeolian where there is essentially no susp transport... revise. The analogy to aeolian dunes is best made with studies that focus on (only) bedload transport and (as reviewed in my Treatise chapter or our CFS II chapter) there are relatively few of these. 

deposition in weak back-eddy flows.

426 flow deflection is greatest at the surface near the base of the lee slope and on the interdune corridor upwind of flow re-attachment where maximum flow expansion and deceleration occur. In this region, the crest-parallel component of the net flow vector has a greater effect on flow deflection, thereby promoting more along-dune oriented flow within the separation cell. As surface flow accelerates beyond re-attachment, vectors gradually deflect back toward bedform-normal up the stoss slope of the downwind dune in response to increases in the crest-transverse component of the net flow vector. This rather simple deflection mechanism explains why, in part, longitudinal flows are observed in the lee (Sharp, 1966; Tsoar, 1983; Tsoar et al., 1985) and, in this case, under relatively transverse incident flow conditions. a differential flow deflection model in the lee of transverse and relatively straight-crested dunes, which is demonstrated conceptually in Figure 9. Based on several non-continuous measurements, which is still common in aeolian research as continuous profiling technologies do not yet exist, this model assumes a linear change in deflection and flow speed with increases in height above the surface. In this conceptual model, flow deflection on the lee slope occurs toward an angle that is more oblique than that of the incident wind, thereby increasing the bedform-parallel component of secondary flow and, if competent, sand transport (discussed further in the following section). Flow vectors and visualization observations both show that the amount of lee-side flow deflection decreases with height above the surface such that flow at/above dune height is less deflected than near-surface flows in response to relatively faster overshot flow above the separation cell (c.f. Walker and Nickling, 2002). Hence, dune-parallel components of the local flow vectors are proportionately less. The relative amount of deflection also increases with incident speed and dune 
450 leeward with increased incident speed, causing the point of maximum deflection above dune height

451 to progress downwind (see |Figure 4). Thus, maximum deflection occurs closer to the dune near

452 the surface and further downwind in the upper wake region (approximately over the toe of the

453 downwind dune). This differential deflection mechanism likely contributes to the development of

454 roller and/or helical vortices in the separation region. Thus, even under relatively transverse flow

455 conditions, longitudinal components of secondary flow patterns may contribute significantly to lee-

456 side momentum transfers and must be considered for characterization and modeling of flow and

457 sediment transport continuity.

Results from other studies show that lee-side flow shifts from a closed-loop recycling roller vortex to a longitudinal (along-dune) helix (c.f. Walker and Nickling, 2002) under slight increases in

flow obliquity from transverse (i.e. from $i=90 \pm 10^{\circ}$ to $\pm 20^{\circ}$ ). For instance, profiles and vectors for

event $4\left(i=110^{\circ}\right.$, Figures 5,7$)$ suggest that flow is separated and has a strong deflected over the larger (east) dune transect. Qualitative flow streamer visualization observations under

similar conditions (not shown here) indicated that the helical vortex was not only less extensive, but also less coherent (i.e. intermittent and poorly developed). Although a recycling helical pattern was observed, it is suggested that this pattern is an intermittent transitional phase between the roller vortex and the attached, deflected flow of more oblique incident conditions. This does not detract, however, from the observation that both deflected along-dune and recycling upslope flow and sediment transport may occur under relatively transverse incident flows (i.e. $70 \leq \mathrm{i} \leq 110^{\circ}$ ) (c.f. Walker, 1999). It follows that, under transporting windspeeds, these patterns could contribute appreciably to dune sediment dynamics, morphology, and migration.

Comment [D24]: lan, did you mean Fig 4, which is now photos of the vis setup or fig 6 (old 4 ), which is the vectors for events 1-3?

Comment [IW25]: Not sure, but it would seem to make sense that we were talking about the profiles here... should also cite W\&N 2002 flow model, specifically the figure, from that paper for reference as it was derived from the same dunes. 
475 transport patterns and the resulting migration of closely spaced transverse dune forms. This study

476 and concurrent research on sand transport patterns by Walker (1999) at the same site shows that

477 competent, deflected secondary interdune flow patterns can transport appreciable amounts of

478 sediment parallel to the crest along the interdune corridor, even under relatively transverse flow conditions. Morphodynamically, then, these patterns may have a significant influence on the direction of dune migration. For instance, along-dune oriented sediment transport and ripple migration were observed during a high-speed storm event that caused migration of the dune crest by approximately $1.25 \mathrm{~m}$ downwind (Figure 10). Direct measurements of lee-side sediment flux during subsequent transporting events at the same study site (Walker, 1999) suggest a threedimensional sediment budget that, under relatively consistent conditions, would promote migration in an oblique direction, rather than in a bedform-normal direction (e.g. Rubin and Hunter, 1987; Rubin and Ikeda, 1990; Lancaster, 1991) (Figure 10). This study shows that in addition to conventional fallout deposition and lee slope avalanching (Anderson, 1988; Anderson and Walker, 2006), other longitudinally oriented transport mechanisms (e.g. alongdune ripple migration, deflected interdune saltation and fallout transport) contribute to transverse dune migration and morphodynamics.

Figure 11 is a stylized empirical model of near surface flow (solid arrows) and deflected sediment transport vectors (dashed short arrows) that occur in the lee of relatively straight transverse dunes. Sediment transport vectors were are interpreted and/or directly measured (from ripples and/or trap measurements, see Walker, 1999) and their patterns represent where sediment mass is directed during the respective driving incident flow conditions. As incident flow becomes less transverse to the crest, lee-side separation cells become less extensive, and flow

Comment [IW29]: At least 2 key studies by the Nickling, Lancaster and Mckenna neuman group need to be cited here... again, I think they were cited in the Anderson and walker paper or in the Treatise chapter.

Comment [IW30]: Again, check fig numbers becaus in the files, fig 10 shows the deflection and transport patterns (with implications we're discussing here). Fix please.

Comment [IW31]: Remove the text part, leave only Walker 1999 in brackets. 
flow becomes less transverse, flow speeds in the lee increase due to the apparent reduction in dune aspect ratio. The effectiveness or overall contribution of these mechanisms, and their relation to migration rates, depends though on secondary flow magnitude, duration, and incident direction and requires more extensive research. Future work should also incorporate issues of dune spacing, as Baddock et al. (2007) have shown that interdune dynamics are strongly influenced by interactions between reattachment and downwind dune stoss positions.

504

\section{CONCLUSIONS}

In order to conserve fluid momentum and sediment mass, deflected components of secondary flow and interdune sand transport must be considered in approaches to model airflow and sediment transport over dunes. Flow separation, reversal, and lateral deflection cause threedimensional variations that, in terms of a budget approach, represent a deficit of fluid mass and transported sediment from simple two-dimensional models. Even under relatively transverse flow conditions, where lee-side flow above the separation cell and downstream of re-attachment may travel in an essentially streamwise direction, lateral deflection occurs in near-surface surface flow and resulting sediment transport. Thus, budget approaches to conceptualizing flow and net sediment transport over dunes should not be viewed simply as a two-dimensional system of bedform-normal components. This study has demonstrated that flow over transverse dunes is deflected in the lee to a degree that increases as incident flow becomes less transverse. As flow becomes increasingly oblique to the crest, the effective aspect ratio (and, hence, form roughness) encountered by the wind decreases and patterns of flow acceleration, separation, and potential recirculation on sediment transport are diminished. Further, oblique incident conditions offer a greater fetch. The implications for sediment transport and dune migration are that transport potential increases with increasing flow obliquity (towards crest-parallel) compared with transverse flows, and that transverse dunes can migrate sideways.
Comment [IW32]: Could make some brief linkage here to Baddock's work and his summary model on interdune regions?

Comment [D33]: You've tried to get me to include discussion of Baddock's stuff a few times now, to the point that I think I'm missing something in his papers! As far as I could remember, he never discusses deflection and his interdune model (2007 paper) is all about dune spacing, which we don't delve into here at all. Am I missing something? Or maybe you get a kickback if you cite him ;)

Comment [IW34]: Also, supply as they had hard interdune surfaces... some review/mention of this in the treatise chapter.

Comment [IW35]: Should elaborate and clarify a bit more with direct reference and explanation of patterns a-d in the figure.

Comment [IW36]: Can't put my finger on it, but I don't like how this ends. The last sentence is off. See earlier wording re: sediment mass transfers, etc. Generaly, see what you can do to beef it up, give it some pizaaz, up the octane, whatever. Also, generally, we should pepper the conclusion with some facts or bullet points to be more concise (for those lazy readers who will only skim the abstract and conclusions). 
Figure 1: Map of study area showing location of the sampling array within transverse ridges on the northern end of the Silver Peak dunefield in western Nevada, USA.

Figure 2: Instrument deployment over west and east sampling transects including location of the flow visualization tower array. Instrument profiles characterize flow within discrete flow regions shown in the upper figure. Vertical axis indicates height of instruments above the lowest elevation in the interdune.

Figure 3: Study site setup. Unwind view (a) of instrument arrays ( $E=e a s t, W=$ west), observation tower $(\mathrm{O})$, flow streamer towers $(\mathrm{F})$; b) dense spacing of vanes and anemometers in the lee on the east transect; c) view of transverse ridges looking NE into the study area (from Walker and Nickling, 2002)

Figure 4: Flow visualization methods. a) 12-m observation tower with perch for aerial viewing of streamer response; b) smoke tracer visualization of lee-side flow patterns and extent of separation cell; c) flow streamer towers extending $9 \mathrm{~m}$ leeward from the crest. Five heights relative to the dune are identified by different symbols. Observation of streamer deflection and smoke patterns were used to complement limited wind vane data in the lee.

Figure 5: Time-averaged wind speed $\left(u / u_{10 h}\right)$ profiles for a series of events $(2,4,7)$ spanning transverse to crest-parallel flow conditions. Note that vertical axis shows sampling heights relative to underlying surface not the interdune datum.

Figure 6: Time-averaged flow vectors for events 1 through 3. Upper values indicate direction (SD) and lower italicised values are speed and [coefficient of variation]. Vectors show directions at 3 levels: surface, crest height $( \pm 30 \mathrm{~cm})$, and at half dune height. White arrows at crest locations are at outer flow (5.2h on east and $4.6 \mathrm{~h}$ on west profiles). Dashed vertical line shows lee slope base and interdune

Figure 7: Time-averaged flow vectors for events 4 and 5. Upper values indicate direction (SD) and lower italicised values are speed and [coefficient of variation]. Vectors show directions at 3 levels: surface, crest height $( \pm 30 \mathrm{~cm})$, and at half dune height. White arrows at crest locations are at outer flow $(5.2 \mathrm{~h}$ on east and $4.6 \mathrm{~h}$ on west profiles). Dashed vertical line shows lee slope base and interdune.

Figure 8: Time-averaged flow vectors for events 6 and 7. Upper values indicate direction (SD) and lower italicised values are speed and [coefficient of variation]. Vectors show directions at 3 levels: surface, crest height $( \pm 30 \mathrm{~cm})$, and at half dune height. White arrows at crest locations are at outer flow (5.2h on east and $4.6 \mathrm{~h}$ on west profiles). Dashed vertical line shows lee slope base and interdune.

Figure 9: Differential deflection of lee-side flow over closely spaced dunes for various incident angles. Vectors are proportionally sized to normalized windspeed and show directional variation from the surface (black) to above dune height (grey). Intermittent (white) and transitional (lines) vectors are also shown.

Figure 10: Evidence for lee-side sediment transport processes over a transverse dune in the Silver Peak dunefield, Nevada. A) active flow separation, suspended fallout, and deflected ripples formed under approximately crest-transverse flow $\left(i \approx 90^{\circ}\right)$; b) along-dune oriented ripples on the lee slope looking east; c) small, bifurcated ripples on the upper lee slope and larger, coarse granule ripples on the base $(5 \mathrm{~cm}$ lens cap for scale). All photos taken in May 1997. Photos $\mathrm{b}$ and $\mathrm{c}$ were taken after the transporting event shown in $\mathrm{a}$. 
Figure 11: Lateral diversion of secondary lee-side flows and surface winds in response to various incidence angles over closely spaced dunes. Short arrows indicate sediment transport direction and dashed arrows indicate intermittent transport.

569 
Anderson JL, Walker IJ. 2006. Airflow and sand transport variations within a backshore-parabolic dune plain complex: NE Graham Island, British Columbia, Canada. Geomorphology 77: 17-34. DOI: 10.1016/j.geomorph.2005.12.008

Anderson RS. 1988. The pattern of grainfall deposition in the lee of aeolian dunes. Sedimentology 35: 175-188. DOI: 10.1111/j.1365-3091.1988.tb00943.x

Arens SM, Van Kaam-Peters HME, Van Boxel JH. 1995. Air flow over foredunes and implications for sand transport. Earth Surface Processes and Landforms 20: 315-332. DOI: 10.1002/esp.3290200403

Baddock M, Livingstone I, Wiggs G. 2007. The geomorphological significance of airflow patterns in transverse dune interdunes. Geomorphology 87: 322-336. DOI: 10.1016/j.geomorph.2006.10.006

Baddock MC, Wiggs GFS, Livingstone I. 2011. A field study of mean and turbulent flow characteristics upwind, over and downwind of barchan dunes. Earth Surface Processes and Landforms 36: 1435-1448. DOI: 10.1002/esp.2161

585 Bagnold RA. 1941 The Physics of Blown Sand and Desert Dunes. Muthuen: London

Best J, Kostaschuk R. 2002. An experimental study of turbulent flow over a low-angle dune. Journal of Geophysical Research 107: 3135. DOI: 10.1029/2000jc000294

588 Bullard JE, Thomas DSG, Livingstone I, Wiggs GFS. 1996. Wind energy variations in the 589 southwestern Kalahari Desert and implications for linear dunefield activity. Earth Surface 590 Processes and Landforms 21: 263-278. DOI: 10.1002/(sici)1096-9837(199603)21:3<263::aid591 esp627>3.0.co;2-i

592 Carson MA, MacLean PA. 1985. Storm-controlled oblique dunes of the Oregon coast: Discussion and reply. Geological Society of America Bulletin 96: 409-410. DOI: 10.1130/00167606(1985)96<409:sodoto>2.0.co;2

Carson MA, MacLean PA. 1986. Development of hybrid aeolian dunes: The William River dune field, Northwest Saskatchewan, Canada. Canadian Journal of Earth Sciences 23: 1974-1990. DOI: 10.1139/e86-183

598 Cooke RU, Goudie AS, Warren A. 1993 Desert Geomorphology. UCL Press: London

599 Frank A, Kocurek G. 1996. Toward a model for airflow on the lee side of aeolian dunes.

600 Sedimentology 43: 451-458. DOI: 10.1046/j.1365-3091.1996.d01-20.x

601 Fryberger SG, Dean G. 1979. Dune forms and wind regimes. In A Study of Global Sand Seas, 602 McKee E (eds), pp. 137-169. U.S. Geological Survey Professional Paper 1052.

603 Gaylord DR, Stetler LD. 1994. Aeolian-climatic thresholds and sand dunes at the Hanford site,

604 south-central Washington, U.S.A. Journal of Arid Environments 28: 95-116. DOI: 10.1016/s0140-

605 1963(05)80041-2

606 Glennie KW. 1970 Desert Sedimentary Environments. Elsevier: Amsterdam

607 Hanna SR. 1969. The formation of longitudinal sand dunes by large helical eddies in the

608 atmosphere. Journal of Applied Meteorology 8: 874-883. DOI: 10.1175/1520-

609 0450(1969)008<0874:tfolsd>2.0.co;2

610 Hesp P, Hyde R, Hesp V, Zhengyu Q. 1989. Longitudinal dunes can move sideways. Earth

611 Surface Processes and Landforms 14: 447-451. DOI: 10.1002/esp.3290140510 
612 Hesp P, Walker IJ. In press. Fundamentals of Aeolian Sediment Transport: Coastal dunes. In

613 Aeolian Geomorphology, Treatise on Geomorphology,(eds), 11. Elsevier, Oxford.

614 Hesp PA. 1981. The formation of shadow dunes. Journal of Sedimentary Research 51: 101-112.

615 DOI: 10.1306/212f7c1b-2b24-11d7-8648000102c1865d

616 Hesp PA. 1983. Morphodynamics of incipient foredunes in New South Wales, Australia. In Eolian 617 Sediments and Processes, Brookfield ME, Ahlbrandt TS (eds), pp. 325-342. Elsevier, Amsterdam

618 Hesp PA, Hyde R. 1996. Flow dynamics and geomorphology of a trough blowout. Sedimentology 619 43: 505-525. DOI: 10.1046/j.1365-3091.1996.d01-22.x

Howard AD. 1985. Interaction of sand transport with topography and local winds in the northern Peruvian coastal desert. In Proceedings of International Workshop on the Physics of Blown Sand, Barndorff-Nielsen OE, Møller JT, Rasmussen KR, Willetts BB (eds). Aarhus, Denmark, 511-544.

Hunter RE, Richmond BM, Alpha TR. 1983. Storm-controlled oblique dunes of the Oregon coast. Geological Society of America Bulletin 94: 1450-1465. DOI: 10.1130/0016-

7606(1983)94<1450:sodoto>2.0.co;2

626

Hunter RE, Richmond BM, Alpha TR. 1985. Storm-controlled oblique dunes of the Oregon coast: Discussion and reply. Geological Society of America Bulletin 96: 410. DOI: 10.1130/0016-

628 7606(1985)96<410:sodoto>2.0.co;2

629 Jackson DWT, Beyers JHM, Lynch K, Cooper JAG, Baas ACW, Delgado-Fernandez I. 2011 Investigation of three-dimensional wind flow behaviour over coastal dune morphology under offshore winds using computational fluid dynamics (CFD) and ultrasonic anemometry. Earth Surface Processes and Landforms 36: 1113-1124. DOI: 10.1002/esp.2139

Jackson PS. 1977. Aspects of surface wind behaviour. Wind Engineering 1: 1-14.

Kocurek G, Lancaster N. 1999. Aeolian system sediment state: theory and Mojave Desert Kelso dune field example. Sedimentology 46: 505-515. DOI: 10.1046/j.1365-3091.1999.00227.x

Kocurek G, Townsley M, Yeh E, Havholm K, Sweet ML. 1992. Dune and dune-field development on Padre Island, Texas, with implications for interdune deposition and water-table-controlled accumulation. Journal of Sedimentary Petrology 62: 622-635. DOI: 10.1306/D4267974-2B2611D7-8648000102C1865D

640

Kostaschuk R (2005) Sediment transport mechanics and dune morphology. In: River, Coastal and

641 Estuarine Morphodynamics: RCEM 2005 (Eds Parker G, Garcia M), pp. 795-803. Taylor \& Francis,

642 London, Urbana, Illinois.

643 Kostaschuk R, Shugar D, Best J, Parsons D, Lane S, Hardy R, Orfeo O. 2009. Suspended

644 sediment transport and deposition over a dune: Rio Parana, Argentina. Earth Surface Processes

645 and Landforms 34: 1605-1611.

646 Kostaschuk RA. 2000. A field study of turbulence and sediment dynamics over subaqueous dunes with flow separation. Sedimentology 47: 519-531. DOI: 10.1046/j.1365-3091.2000.00303.x 649 Fraser River, Canada. Sedimentology 43: 849-863. DOI: 10.1111/j.1365-3091.1996.tb01506.x

650 Lancaster N. 1982. Linear dunes. Progress in Physical Geography 6: 476-504. DOI:

$651 \quad 10.1177 / 030913338200600401$

652 Lancaster N. 1983. Controls of dune morphology in the Namib sand sea. In Developments in 653 Sedimentology, 38, Ahlbrandt TS, Brookfield ME (eds), 38, pp. 261-289. Elsevier, Amsterdam. 
654 Lancaster N. 1991. The orientation of dunes with respect to sand-transporting winds: a test of

655 Rubin and Hunter's gross bedform-normal rule. Acta Mechanica Supplementum 2: 89-102.

656 Lancaster N. 1995 The Geomorphology of Desert Dunes. Routledge: London

657 Lancaster N, Helm P. 2000. A test of a climatic index of dune mobility using measurements from

658 the southwestern United States. Earth Surface Processes and Landforms 25: 197-207. DOI:

659 10.1002/(sici)1096-9837(200002)25:2<197::aid-esp82>3.0.co;2-h

660 Livingstone I, Wiggs GFS, Weaver CM. 2007. Geomorphology of desert sand dunes: A review of recent progress. Earth-Science Reviews 80: 239-257.

662 Lynch K, Jackson DWT, Cooper JAG. 2008. Aeolian fetch distance and secondary airflow effects:

663 the influence of micro-scale variables on meso-scale foredune development. Earth Surface

664 Processes and Landforms 33: 991-1005. DOI: 10.1002/esp.1582

665 Lynch K, Jackson DWT, Cooper JAG. 2009. Foredune accretion under offshore winds.

666 Geomorphology 105: 139-146. DOI: 10.1016/j.geomorph.2007.12.011

667 Lynch K, Jackson DWT, Cooper JAG. 2010. Coastal foredune topography as a control on

668 secondary airflow regimes under offshore winds. Earth Surface Processes and Landforms 35: 344-

669 353. DOI: $10.1002 /$ esp.1925

670 Mabbut JA, Jennings JN, Wooding RA. 1969. The asymmetry of Australian desert sand ridges.

671 Australian Journal of Science 32: 159-160.

672 McCauley CK, Breed WJ. 1980. Topographically controlled dune systems on Earth and Mars. In 673 Aeolian Processes and Landforms: Reports of Planetary Geology Program, Wirth P, Greeley R,

674 D'Alli RE (eds), TM-81776, pp. 255-56. National Aeronautics and Space Administration.

675 Mikkelsen HE. 1989 Wind flow and sediment transport over a low coastal dune. GeoSkrifter 32,

676 Geologisk Institut, University of Aarhus: Aarhus

677 Muhs DR, Holliday VT. 1995. Evidence of active dune sand on the Great Plains in the 19th century 678 from accounts of early explorers. Quaternary Research 43: 198-208.

679 Muhs DR, Maat PB. 1993. The potential response of eolian sands to greenhouse warming and 680 precipitation reduction on the Great Plains of the U.S.A. Journal of Arid Environments 25: 351-361.

681 DOI: 10.1006/jare.1993.1068

682 Muhs DR, Wolfe SA. 1999. Sand dunes of the northern Great Plains of Canada and the United 683 States. In Holocene climate and environmental change in the Palliser Triangle: a geoscientific 684 context for evaluation the impacts of climate change on the southern Canadian prairies, Lemmen 685 DS, Vance RE (eds), pp. 183-197. Geological Survey of Canada, Bulletin 534

686 Ould Ahmedou D, Ould Mahfoudh A, Dupont P, Ould El Moctar A, Valance A, Rasmussen KR.

687 2007. Barchan dune mobility in Mauritania related to dune and interdune sand fluxes. Journal of

688 Geophysical Research 112. DOI: 10.1029/2006jf000500

689 Pearce KI, Walker IJ. 2005. Frequency and magnitude biases in the 'Fryberger' model, with 690 implications for characterizing geomorphically effective winds. Geomorphology 68: 39-55. DOI:

691 10.1016/j.geomorph.2004.09.030

692 Rasmussen KR. 1989. Some aspects of flow over coastal dunes. Proceedings of the Royal Society of Edinburgh Section B: Biology 96: 129-147. DOI: doi:10.1017/S0269727000010897

694 Rubin $\mathrm{CM}$, Ikeda H. 1990. Flume experiments on the alignment of transverse, oblique and

695 longitudinal dunes in directionally varying flows. Sedimentology 37: 673-684. DOI: 10.1111/j.1365-

696 3091.1990.tb00628.x 

Processes and Landforms 15: 1-4. DOI: 10.1002/esp.3290150102

Rubin DM, Hunter RE. 1985. Why deposits of longitudinal dunes are rarely recognized in the geologic record. Sedimentology 32: 147-157. DOI: 10.1111/j.1365-3091.1985.tb00498.x

Rubin DM, Hunter RE. 1987. Bedform alignment in directionally varying flows. Science 237: 276278. DOI: 10.1126/science.237.4812.276

703 Sharp RP. 1966. Kelso dunes, Mojave Desert, California. Geological Society of America Bulletin 77: 1045-1073. DOI: 10.1130/0016-7606(1966)77[1045:KDMDC]2.0.CO;2

Smith JD, McLean SR. 1977. Spatially Averaged Flow Over a Wavy Surface. Journal of Geophysical Research 82: 1735-1746. DOI: 10.1029/JC082i012p01735

Svasek JN, Terwindt JHJ. 1974. Measurements of sand transport by wind on a natural beach. Sedimentology 21.

Sweet ML, Kocurek G. 1990. An empirical model of aeolian dune lee-face airflow. Sedimentology 37: 1023-1038. DOI: 10.1111/j.1365-3091.1990.tb01843.x

Tsoar H. 1983. Dynamic processes acting on a longitudinal (seif) sand dune. Sedimentology 30: 567-578. DOI: 10.1111/j.1365-3091.1983.tb00694.x

Tsoar H. 2002. Climatic factors affecting mobility and stability of sand dunes. In Proceedings of ICAR5/GCTE-SEN Joint Conference, Lee JA, Zobeck TM (eds).Center for Arid and Semiarid Lands Studies: Texas Tech University, Lubbock, 423.

Tsoar H, Illenberger W. 1998. Re evaluation of sand dunes' mobility indices. Journal of Arid Lands Studies 7S: 265-268.

Tsoar H, Rasmussen KR, Sorensen M, Willetts BB. 1985. Laboratory studies of flow over dunes. In Proceedings of International Workshop on the Physics of Blown Sand, Barndorff-Nielsen OE, Møller JT, Rasmussen KR, Willetts BB (eds). Aarhus, Denmark, 271-300.

Walker IJ. 1999. Secondary airflow and sediment transport in the lee of a reversing dune. Earth Surface Processes and Landforms 24: 437-448. DOI: 10.1002/(sici)1096-

9837(199905)24:5<437::aid-esp999>3.0.co;2-z

Walker IJ. 2000. Secondary airflow and sediment transport in the lee of transverse dunes, University of Guelph, Guelph, 256 pp.

Walker IJ, Hesp P. In press. Fundamentals of Aeolian Sediment Transport: Airflow over dunes. In Aeolian Geomorphology, Treatise on Geomorphology,(eds), 11. Elsevier, Oxford.

Walker IJ, Hesp PA, Davidson-Arnott RGD, Bauer BO, Namikas SL, Ollerhead J. 2009.

Responses of three-dimensional flow to variations in the angle of incident wind and profile form of dunes: Greenwich Dunes, Prince Edward Island, Canada. Geomorphology 105: 127-138. DOI: 10.1016/j.geomorph.2007.12.019

Walker IJ, Hesp PA, Davidson-Arnott RGD, Ollerhead J. 2006. Topographic steering of alongshore airflow over a vegetated foredune: Greenwich Dunes, Prince Edward Island, Canada. Journal of Coastal Research 22: 1278-1291. DOI: 10.2112/06a-0010.1

Walker IJ, Nickling WG. 2002. Dynamics of secondary airflow and sediment transport over and in the lee of transverse dunes. Progress in Physical Geography 26: 47-75. DOI:

10.1191/0309133302pp325ra

738 Warren A. 1976. Dune trend and the Ekman spiral. Nature 259: 653-654. DOI: 10.1038/259653a0 
739 Wasson RJ, Hyde R. 1983. Factors determining desert dune type. Nature 304: 337-339. DOI:

$74010.1038 / 304337 \mathrm{a} 0$

741 Weaver CM, Wiggs GFS. 2011. Field measurements of mean and turbulent airflow over a barchan

742 sand dune. Geomorphology 128: 32-41.

743 Wiggs GFS. 2001. Desert dune processes and dynamics. Progress in Physical Geography 25: 53744 79. DOI: $10.1177 / 030913330102500103$

745 Wiggs GFS, Livingstone I, Thomas DSG, Bullard JE. 1996. Airflow and roughness characteristics

746 over partially vegetated linear dunes in the southwest Kalahari Desert. Earth Surface Processes

747 and Landforms 21: 19-34. DOI: 10.1002/(sici)1096-9837(199601)21:1<19::aid-esp508>3.0.co;2-p

748 Wiggs GFS, Thomas DSG, Bullard JE, Livingstone I. 1995. Dune mobility and vegetation cover in

749 the Southwest Kalahari desert. Earth Surface Processes and Landforms 20: 515-529. DOI:

750 10.1002/esp.3290200604

751 Wilson IG. 1972. Aeolian bedforms - their development and origins. Sedimentology 19: 173-210.

752 DOI: 10.1111/j.1365-3091.1972.tb00020.x

753 Wolfe SA. 1997. Impact of increased aridity on sand dune activity in the Canadian Prairies. Journal

754 of Arid Environments 36: 421-432. DOI: 10.1006/jare.1996.0236

755

756

757 
763

\begin{tabular}{|c|c|c|c|c|c|c|c|}
\hline Event & $\begin{array}{c}\text { Time } \\
\text { [duration] }\end{array}$ & $\begin{array}{c}\text { Direction } \\
\left(^{\circ}\right)\end{array}$ & $\begin{array}{l}\text { SD } \\
\left({ }^{\circ}\right)\end{array}$ & $\begin{array}{c}\text { Incident speed } \\
\left(\mathrm{u}_{5.2 \mathrm{~h}}, \mathrm{~m} \mathrm{~s}^{-1}\right) \\
{[\text { average] }}\end{array}$ & $\begin{array}{l}C V \\
\left(u_{i}\right)\end{array}$ & $\begin{array}{c}\text { crest } \\
\text { speed } \\
\mathrm{u}_{0.3} / \mathrm{u}_{12}\end{array}$ & $\begin{array}{l}\text { lee-side } \\
\text { speeds } \\
\mathrm{u}_{0.3} / \mathrm{u}_{12}\end{array}$ \\
\hline $1 \mathrm{E}$ & $19: 18-19: 35$ & 91 & 4.9 & $3.8-5.5[4.59]$ & 0.10 & 0.82 & $0.41-0.59$ \\
\hline $1 \mathrm{~W}$ & 50.10 & 89 & & $4.2-5.6[4.84]$ & 0.09 & 0.90 & $0.47-0.73$ \\
\hline $2 \mathrm{E}$ & $19: 43-20: 01$ & 89 & 3.5 & $5.4-7.7[6.54]$ & 0.10 & 0.79 & $0.30-0.52$ \\
\hline $2 \mathrm{~W}$ & {$[0: 20]$} & 88 & 2.6 & $5.6-8.0[6.91]$ & 0.10 & 0.87 & $0.37-0.53$ \\
\hline $3 \mathrm{E}$ & $21: 03-21: 23$ & 89 & 5.5 & $7.6-10.0[8.83]$ & 0.09 & 0.73 & $0.27-0.51$ \\
\hline $3 \mathrm{~W}$ & {$[0: 21]$} & 89 & 5.6 & $8.2-10.5[9.17]$ & 0.07 & 0.80 & $0.35-0.50$ \\
\hline $4 \mathrm{E}$ & $3: 10-3: 33$ & 111 & 3.6 & $3.9-5.6[6.27]$ & 0.09 & 0.79 & $0.44-0.61$ \\
\hline $4 \mathrm{~W}$ & {$[0.24]$} & 110 & 3.5 & $5.5-7$ & 0.08 & 0.88 & $0.54-0.81$ \\
\hline $5 \mathrm{E}$ & $4: 51-5: 11$ & 131 & 3.9 & $4.7-6.7[5.74]$ & 0.11 & 0.70 & $0.52-0.78$ \\
\hline $5 \mathrm{~W}$ & {$[0: 21]$} & 130 & 3.9 & $4.9-7.1[5.98]$ & 0.09 & 0.77 & $0.53-0.79$ \\
\hline $6 \mathrm{E}$ & $2: 34-2: 52$ & 146 & 5.3 & $5.4-7.6[6.52]$ & 0.10 & 0.69 & $0.59-0.80$ \\
\hline $6 \mathrm{~W}$ & {$[0: 19]$} & 146 & 5.3 & $5.1-7.3[6.32]$ & 0.10 & 0.73 & $0.61-0.84$ \\
\hline $7 \mathrm{E}$ & $1: 29-1: 35$ & 3 & 2.6 & $4.5-5.5[4.96]$ & 0.08 & 0.60 & $0.63-0.67$ \\
\hline $7 \mathrm{~W}$ & {$[0: 07]$} & 2 & 3.6 & $3.9-5.1[4.47]$ & 0.10 & 0.58 & $0.59-0.75$ \\
\hline
\end{tabular}
Summary of wind events recorded on east $(\mathrm{E})$ and west $(\mathrm{W})$ sampling transects ordered
from relatively transverse conditions to crest-parallel flow. Note that flow from the west is $0^{\circ}$ east is $180^{\circ}$. Data are based on 1 minute averages sampled at $1 \mathrm{~Hz}$ (e.g. $u_{5.2 \mathrm{~h}}=$ incident speed at $3.8 \mathrm{~m}$ above east dune crest, $\mathrm{SD}=$ standard deviation, $\mathrm{CV}=$ coefficient of variation $\left.=\mathrm{SD}_{\mathrm{u} 5.2 \mathrm{~h}} / \mathrm{u}_{5.2 \mathrm{~h}},\right)$. All events were recorded on the same day (1997 JD 155).

764 